\title{
EXAMINING THE ROLE OF VIDEO-RECORDED SPEAKING TASK IN ENHANCING STUDENTS' ORAL PRODUCTIVE SKILL
}

\author{
Siti Nurul Azkiyah', Rahmi Rahayu ${ }^{2}$ \\ ${ }^{1}$ Syarif Hidayatullah State Islamic University of Jakarta, Indonesia \\ ${ }^{2}$ BSD Al-Fath Islamic School, Indonesia \\ (azkiyah@uinjkt.ac.id)
}

Received: $07^{\text {th }}$ Sepetember 2018; Revised: $16^{\text {th }}$ October 2018; Accepted: $28^{\text {th }}$ Desember 2018

\begin{abstract}
The teaching of speaking in Indonesian schools faces some problems such as limited amount of practice and feedback and students' anxiety. Addressing this issue, therefore, this study was aimed at examining the role of video-recorded speaking task in improving students' oral productive skill measured through a speaking test and understand students' response on the use of the task through a questionnaire. It was a quasi-experimental study, the sample of which was 87 tenth grade students of one senior high selected through a purposive sampling technique and randomly assigned into experimental and controlled classes. The test served as a pretest administered at the beginning and as a posttest distributed at the end of the treatment, which data were analyzed using t-test. The effectiveness of the treatment was analyzed from the posttest and gained scores, which findings revealed higher achievements of the experimental group. In addition, students were happy to do this task. These findings mean that video-recorded speaking task play roles in enhancing students' oral productive skill and support previous studies on the effectiveness of video-recorded speaking tasks.
\end{abstract}

Keywords: speaking; the teaching of speaking; teaching instruction; video-recorded speaking task; quasi-experimental design

\section{ABSTRAK}

Pengajaran berbicara di banyak sekolah di Indonesia menghadapi berbagai masalah, diantaranya terbatasnya waktu untuk praktik keterampilan berbicara dan feedback oleh guru serta keengganan siswa untuk berlatih. Untuk menjawab tantangan, studi ini ditujukan untuk menguji peran tugas berbicara yang divideokan dan pendapat siswa terhadap diberlakukannya tugas ini. Studi ini menggunakan desain kuasi-experiment dengan purposive sampling yang kemudian secara acak dibagi menjadi kelas eksperimen dan kelas kontrol. Tes dilakukan 2 kali sebagai pretest dan posttest, di mana data posttest dan gain score dianalisis menggunaan uji t-test. Hasil analisis menunjukkan bahwa nilai keterampilan berbicara kelas eksperimen secara signifikan lebih tinggi. Selain itu, siswa juga senang mengerjakan tugas ini. Temuan ini menunjukkan bahwa pemberian tugas berbicara dengan divideokan bisa meningkatkan kemampuan produktif secara oral dan mendukung temuan terdahulu terkait efektifitas tugas berbicara yang divideokan.

Kata kunci: keterampilan berbicara; pengajaran keterampilan berbicara; pembelajaran; tugas berbicara dengan divideokan; desain kuasi-eksperimen

How to Cite: Azkiyah, S. N., Rahayu, R. (2018). Examining the Role of Video-Recorded Speaking Task in Enhancing Students' Oral Productive Skill. IJEE (Indonesian Journal of English Education), 5(2), 204-218. doi:10.15408/ijee.v5i2. 11193.

IJEE (Indonesian Journal of English Education), 5 (2), 2018, 204-218

P-ISSN: 2356-1777, E-ISSN: 2443-0390 | DOI: http://dx.doi.org/10.15408/ijee.v5i2. 11193

This is an open access article under CC-BY-SA license (https://creativecommons.org/licenses/by-sa/4.0/) 


\section{INTRODUCTION}

There has been an argument that speaking is a very important skill in English language learning since English has a powerful position as a means of international communication (Crystal, 2003). Speaking is also often considered to greatly contribute to one's image of language competence (Pishkar, Moinzadeh, \& Dabaghi, 2017). Furthermore, some studies have showed significant roles of speaking ability on students' personal, academic, and professional success (Gunn, 2007; Morreale \& Pearson, 2008).

However, speaking ability has been widely considered to be a more stressful language skill to acquire compared to other skills (Young, 1992; Liu, 2009; Öztürk and Gürbüz, 2014) especially for countries where learners share one common language of instruction and have little exposure to the target language. This could due to the fact that speaking requires interaction among the speakers and the listeners so that communication can take place smoothly. When interacting with others, in addition to verbal communication, paralinguistic elements of speech such as stress, pitch and intonation are other important aspects should be taken into account (Fulcher, 2003). Similarly, speakers also need to acquire communicative competence which relates to the knowledge of language use, language discourse, strategic competence, and sociolinguistic competence (Harmer, 1991; Canale \&
Swain, 1980, Richard \& Rodgers, 2001). Finally, speakers need to combine and activate those elements in the speaking in order to attain the purpose of communication.

As a result, many students have been reported to be under pressure and anxious once they are asked to communicate in English even in the classroom (Oxford, 2002). Research has indicated that the fear of speaking is a common phobia among students. An old study conducted by Richmond and McCroskey (1998) revealed that around $70 \%$ students experienced anxiety in speaking while a more recent study found the percentage was closer to $61 \%$ (Dwyer \& Davidson, 2012).

Indonesia as the context of the study also faces similar problem. The status of English as a foreign language (EFL) in Indonesia contributes the problem of limited opportunities to practice spoken English in both inside and outside the classroom. Most of the time, students only have the opportunity to communicate in English inside the classroom, which normally accommodates more than 35 students during $2 \times 45$ minutes per week. The large size of most Indonesian classes has worsened the situation because teachers have less focus on students' speaking skill at once during the teaching and learning process. Furthermore, the demand of learning speaking is not obvious because most students especially in rural areas live in environment where English is not really 
necessary yet. Despite the fact that ASEAN Economic Community has come, it seems that both teachers and students in Indonesia do not yet have a strong reason to train their speaking ability in English.

In addition, the national exam in Indonesia also focuses more on reading, which leads to the less attention paid to speaking by both teachers and students. Consequently, as has been argued by Gebhard ( 2006), some students only study English as one of the requisites to complete their study. The next important problems come from some constraints of speaking English. According to Hammer (2007), some learners often cannot figure out what they should orally state, do not have sufficient time to prepare and may underestimate their own ability due to much shyness and worries. These constraints are considered to be the factors of foreign language anxiety (Marwan, 2008), which consequently require necessary actions from the teachers to motivate and engage students in classroom activities to provide learning opportunities for the students to practice their oral productive skill, namely speaking.

In this case, the role of teacher is certainly necessary. This is because teacher is the most important actor in facilitating and implementing any innovation in the classroom (Azkiyah, Doolaard, Creemers, \& Van Der Werf, 2014, Azkiyah, 2017). Referring to the proponents of education standards, teachers are expected to seek appropriate classroom instruction to enable all students regardless of their background to achieve the minimum goals as stated in the standards (Chambers \& Dean, 2000; Dowson, McInerney, \& Van Etten, 2007).

Considering the problems of teaching speaking and the important roles of teachers, it is therefore urgent for teachers to find an appropriate technique to provide better learning opportunity for students to develop their speaking ability. Based on the literature review, some techniques such as video-recorded speaking tasks (Dal, 2012), role play (Liu, 2013; Cheng \& Han-Yin, 2008; Sturiale \& Ann, 2013), small group discussion (Yarahmadi, Bonyadi \& Rimaninikou, 2015), brainstorming (Ali, Mohammad \& Jamal, 2015) and game (Leon \& Cely, 2010) have been used to enhance students' speaking ability.

Among these techniques, the one integrated with technology is considered to be more appropriate since it can promote fun and joyful learning. Currently, most students have had easy access to technology, such as mobile phone, internet, and computer, which have even been integral parts of their life and therefore makes the immersion of technology for language teaching possible. Moreover, a study conducted by Shahsavar and Hoon (2011) has proved that using technology for learning gives positive impact to the learners and could serve as an 
alternative form of language learning process.

In this context, mobile phone can be used as the devise to video-record the speaking tasks, in which students can review and improve their own performances without any hesitation since they can do it themselves. The effectiveness of mobile phones for language learning has been investigated by some such as review conducted by Jeng, Huang, \& Tang (2010) and experimental studies carried out by Chen and Hsu (2008), and Tai (2012). The features and programs available in mobile phones have been considered to be able to facilitate language learning in the areas of vocabulary, grammar, phonetics, speaking and reading comprehension (Miangah \& Nezarat, 2012).

In this paper, video-recorded speaking task, which combines both face-to-face teaching and learning process and technology, is preferred because they address the aferomentioned prolems in speaking classroom in EFL context especially the limited amount of practice and students' anxiety. In addition, since most students own mobile phones, they can learn anywhere and anytime using their mobile. Video-recorded speaking task provides the extension of learning speaking and decreases students' anxiety in speaking (Dal, 2012). Utilizing camera in mobile phones, teachers can use task-based language learning as the approach, in which teacher can offer concrete actions to develop students' speaking ability by asking students to produce video-recorded speaking tasks and providing individual feedback and meaningful communication. A number of studies has been conducted to examine the effectiveness of video-recorded speaking tasks which findings reveal that the activities work well and result in the improvement of students' performance (Castaneda \& Gonzales, 2011; Gromik, 2013; Karasic \& Vedantham, 2015)

Furthermore, Dal (2012) argues that the use of video recording supports the principles of teaching a foreign language. In addition, Harmer (2007) adds some more advantageous of using video in speaking such as the freedom and the authentic setting for the students to deliver their thoughts, feelings, and views without any hesitation since they can do it on their own and repeat it any time they like. Also, it provides more time to expose speaking which is limited in the classroom teaching and learning process.

In Indonesian context where English is taught only in two-90 minute meeting per week for all four skills, the use of video recording is considered to be more appropriate because it allows individual students to have additional practice and receive feedback for improvement, which then is expected to improve students' performance. It is therefore hypothesized in this study 
that video-recorded speaking task plays effective roles in enhancing students' oral productive skill ability. In addition, it is also considered important to understand students' responses on the use of video-recorded speaking task because they can serve as the feedback for better implementation of video-recorded speaking task. Hence, students' opinion on the tasks is collected.

\section{METHOD}

This research was a pretest posttest quasi-experimental study intended to examine the role of one variable on another variable by isolating, controlling, and manipulating the variable in real world setting (Cohen, Manion, \& Morrison, 2000). In this study, as has been indicated, the effectiveness of video-recorded tasks in improving students' speaking ability was examined.

In the pretest, students were required to tell a story of their past experience based on the topics provided by the teacher according to the material they learned in the class i.e. Video-recorded speaking tasks have combined both face-to-face teaching and learning process and technology, which can address the aforementioned problems in speaking classroom in EFL context because it provides the extension of learning speaking and decreases students' anxiety in speaking (Dal, 2012). The $t$-test result of the pretest, $\mathrm{t}(85)=0.25, \mathrm{p}=0.18$, revealed no significant difference between the experimental $(\mathrm{M}=77.15, \mathrm{SD}=3.24)$ and control $(\mathrm{M}=76.99, \mathrm{SD}=2.73)$ groups. Thus, both groups had equal ability before the treatment, which was an important condition for an experimental study.

The treatment took place for 2 months (8 meetings including the pretest and posttest), in which students in the experimental group produced three video-recorded speaking tasks, each lasted for two to three minutes. Each video production was followed by individual feedback to improve students' speaking performance, which was given in written form and delivered to the students two days after collecting the videos. Only students in the experimental group used video-recorded speaking task and the other group used regular teaching method. In order to measure the role of video-recorded speaking task, the post-test was administered to both groups.

In assessing both the pretest and posttest, scoring rubric proposed by Harris (1969) was used as the guideline. The rubric was arranged in rating scale for five criteria of the elements of speaking skill. They are pronunciation, grammar, vocabulary, fluency, and comprehension. Furthermore, a questionnaire, consisted of five open-ended questions, was also used as the instrument to ask students' views of the use of video-recorded speaking task. 
In order to examine the effectiveness of the experiment, both the gain and posttest scores were analyzed using $t$-test. Preliminary analysis were previously carried out to check the normality (Kolmogorov-Smirnov) and homogeneity (Levene) of the data, which results showed that the data were both normally distributed and homogeneous. The significance level accepted in this study was $p=.05$. The data from student questionnaire was descriptively analyzed to understand students' opinion on the use of video-recorded speaking task.

The study was conducted in in one senior high school in one district in Banten province, Indonesia. Senior high school students were selected as the sample of the study due to the reason that they have been learning English for at least 5 years and were assumed to own mobile phones. Referring to the permission of the school, two classes of the tenth grade students (87 students, 55 girls and 32 boys) were selected as the participants of this study. The classes were randomly assigned into the control class (44 students) and the experimental class (43 students).

\section{FINDINGS AND DISCUSSIONS}

\section{Findings}

The Pretest, Posttest, and Gain Scores: A comparison

Both the row scores of pretest and posttest were classified into three categories: low, middle, and high. The low scores were those lower than 70, which meant that students did not achieve the minimum standards as set in the curriculum. The middle scores ranged from 70 to 80 , and the high scores were 81 and above. The classification of the score could be seen in the Table 1.

Table 1. The Score of Pre-Test

\begin{tabular}{lllll}
\hline \multirow{2}{*}{ Score } & \multicolumn{2}{l}{$\begin{array}{l}\text { Experimental } \\
\text { Class }\end{array}$} & \multicolumn{2}{l}{ Controlled } \\
& Freq. & $\%$ & Freq. & $\%$ \\
\cline { 2 - 5 } & 2 & 4.65 & 2 & 4.54 \\
\hline$*<70$ & 32 & 74.42 & 36 & 81.82 \\
$70-80$ & 9 & 20.93 & 6 & 13.64 \\
$81-90$ & & 77.15 & $76.99(2.73)$ \\
\hline Mean Score & & $(3.24)$ & & \\
& &
\end{tabular}

Note: $\left.{ }^{*}\right)$ below the standard of minimum completeness

Table 1 clearly presents that in the pretest score, both the experimental and control groups had two students who scored below the standards of completeness. There were more students in the control group (82\%) than in the experimental group (74\%) who fell in the middle score. However, the experimental group (21\%) had higher percentage of students who scored high than the control group (13\%).

Furthermore, the most important information from Table 1 is that students in both the experimental and control groups achieved nearly the same in average: the mean score of the experimental group is 77.15 while that of the control group is 76.99. As previously indicated, the t-test result revealed that both classes did not have 
statistically significant difference. This finding indicates that both the experimental and control groups started from the same point. In other words, they had the same characteristic in terms of the ability before the treatment, which was an important condition in any type of experimental design, including quasi experimental one.

Table 2. The Score of Post-Test

\begin{tabular}{lllll}
\hline \multirow{2}{*}{ Score } & \multicolumn{2}{l}{$\begin{array}{l}\text { Experimental } \\
\text { Class }\end{array}$} & \multicolumn{3}{l}{$\begin{array}{l}\text { Controlled } \\
\text { Class }\end{array}$} \\
\cline { 2 - 5 } & Freq. & $\%$ & Freq. & $\%$ \\
\hline$*<70$ & - & 0 & - & 0 \\
$70-80$ & 22 & 51.16 & 31 & 70.45 \\
$81-90$ & 21 & 48.84 & 13 & 29.55 \\
\hline Mean Score & & 80.19 & $78.57(2.77)$ \\
& & $(3.82)$ & & \\
\end{tabular}

Note: $\left({ }^{*}\right)$ below the standard of minimum completeness

After the treatment finished, as indicated in Table 2, there were no students in both the experimental and control groups who did not reach the minimum standards set in the curriculum. Differences between the two groups were observed in the percentage of students in the middle and high scores. There were more students in the experimental group who scored high whereas more students in the control group scored medium. Nearly $50 \%$ of students in the experimental group achieved between $81-90$, while $70 \%$ of students in the control group reached between $71-80$. In average, the mean score of the experimental group was 80.19 while that of the control group was 78.57.

Furthermore, gained score was also analyzed, in which differences between the experimental and control groups were also observed, as shown in Table 3. In this table, four categories were presented in order to show the gain score in more detail.

Table 3. The Gained Score

\begin{tabular}{|c|c|c|c|c|}
\hline \multirow[t]{2}{*}{$\begin{array}{l}\text { Gained } \\
\text { Score }\end{array}$} & \multicolumn{2}{|c|}{$\begin{array}{l}\text { Experimental } \\
\text { Class }\end{array}$} & \multicolumn{2}{|c|}{$\begin{array}{l}\text { Controlled } \\
\text { Class }\end{array}$} \\
\hline & Freq. & \% & Freq. & $\%$ \\
\hline$<0$ & 3 & 7 & 6 & 14 \\
\hline $0-2$ & 18 & 42 & 30 & 68 \\
\hline 3-5 & 19 & 44 & 8 & 18 \\
\hline 6-8 & 3 & 7 & 0 & 0 \\
\hline Mean & 3 & & 1.5 & \\
\hline
\end{tabular}

Table 3 informs that there were students in both the experimental and control groups who did not improve at all, and therefore did not have any gain. It is important to highlight here that most students in the experimental groups gained from $0-5: 42 \%$ of them gained $0-2$ and $44 \%$ gained $3-5$. In addition, $7 \%$ of them gained $6-8$. Different from this, $68 \%$ of students in the control group gained $0-2$ and only $18 \%$ gained 3 - 5. Furthermore, no students in the control group gained $6-$ 8. 
Table 4 . The Areas of Improvement

\begin{tabular}{|c|c|c|c|c|}
\hline \multirow{2}{*}{$\begin{array}{l}\text { Speaking } \\
\text { Elements }\end{array}$} & \multicolumn{2}{|c|}{$\begin{array}{l}\text { Experimental } \\
\text { Class }\end{array}$} & \multicolumn{2}{|c|}{$\begin{array}{l}\text { Controlled } \\
\text { Class }\end{array}$} \\
\hline & $\begin{array}{l}\text { Gained } \\
\text { Score }\end{array}$ & $\%$ & $\begin{array}{l}\text { Gained } \\
\text { Score }\end{array}$ & $\%$ \\
\hline $\begin{array}{l}\text { Pronunci } \\
\text { ation }\end{array}$ & 156 & $\begin{array}{l}23.8 \\
9\end{array}$ & 114 & $\begin{array}{l}32.7 \\
6\end{array}$ \\
\hline $\begin{array}{l}\text { Gramma } \\
\text { r }\end{array}$ & 82 & $\begin{array}{l}12.5 \\
6\end{array}$ & 82 & $\begin{array}{l}23.5 \\
6\end{array}$ \\
\hline $\begin{array}{l}\text { Vocabul } \\
\text { ary }\end{array}$ & 93 & $\begin{array}{l}14.2 \\
4\end{array}$ & 48 & $\begin{array}{l}13.7 \\
9\end{array}$ \\
\hline Fluency & 155 & $\begin{array}{l}23.7 \\
4\end{array}$ & 64 & $\begin{array}{l}18.3 \\
9\end{array}$ \\
\hline $\begin{array}{l}\text { Compre } \\
\text { hension }\end{array}$ & 167 & $\begin{array}{l}25.5 \\
7 \\
\end{array}$ & 40 & $\begin{array}{l}11.4 \\
9\end{array}$ \\
\hline $\begin{array}{l}\text { Mean } \\
\text { Score } \\
\end{array}$ & $3.04(1.88$ & & $1.58(1.58$ & \\
\hline
\end{tabular}

Concerning the areas of improvement, it is clearly observed that pronunciation (23.89\%), fluency (23.74\%), and comprehension (25.57\%) were the areas where the experimental group improved the most. On the other hand, the control class enhanced the most only in two areas namely pronunciation $(32.76 \%)$ and grammar $(23.56 \%)$. These findings seem to indicate that there was an effective role of video-recorded tasks in improving students' oral productive skill, which will be examined in the following section.

\section{The Role of Video-Recorded Tasks}

This research was intended to measure the role of video-recorded speaking tasks in improving students' oral productive skill at the tenth grade of one senior high school. For this purpose, the scores of posttest of the experimental and control groups were compared using t-test. In addition, the gain scores were also calculated in order to compare the improvement rate of both groups.

Table 5. Independent Sample Test of Gained Score

\begin{tabular}{|c|c|c|c|c|c|c|c|c|c|c|}
\hline & & $\begin{array}{l}\text { Levene's T } \\
\text { Equality } \\
\text { Variances }\end{array}$ & $\begin{array}{r}\text { est fo } \\
\text { o }\end{array}$ & $\begin{array}{l}r \\
f \\
\text { t-test }\end{array}$ & for Equ & lity of Mea & & & & \\
\hline & & & & & & Sig. & Mean & Std. Erro & $\begin{array}{l}95 \% \\
\text { Interval } \\
\text { rDifferer }\end{array}$ & $\begin{array}{l}\text { Confidence } \\
1 \text { of the } \\
\text { nce }\end{array}$ \\
\hline & & $\mathrm{F}$ & Sig. & $\mathrm{T}$ & $\mathrm{df}$ & (2-tailed) & Difference & Difference & Lower & Upper \\
\hline Score & \begin{tabular}{|l} 
Equal \\
variances \\
assumed
\end{tabular} & 2.38 & .13 & 3.90 & 85 & .000 & 1.46 & .37 & .71 & 2.20 \\
\hline & \begin{tabular}{|l} 
Equal \\
variances \\
not \\
assumed
\end{tabular} & & & 3.90 & 81.88 & .000 & 1.46 & .37 & .71 & 2.20 \\
\hline
\end{tabular}


As previously stated, both the experimental and control groups did not have any difference in their pretest scores. After the treatment, the t-test of the post-test scores, $\mathrm{t}(85)=0.27, \mathrm{p}=0.03$, showed that the experimental groups achieved significantly higher $(\mathrm{M}=80.19$, $\mathrm{SD}=3.82)$ and control group $(\mathrm{M}=78.57$, $\mathrm{SD}=2.77)$. Similarly, the analysis of the gain scores, $t(85)=3.90, p=0.00$, also depicted that the experimental group $(\mathrm{M}=3.04, \mathrm{SD}=1.88)$ had significantly higher score compared to the control group ( $\mathrm{M}=1.58, \mathrm{SD}=1.58)$. In short, both the post-test and gain scores displayed higher achievement of the experimental group. Thus, the study proves that video-recorded speaking task has an effective role in enhancing students' oral productive skill.

Students' Views of The Use of Video-Recorded Speaking Task

The questionnaire was distributed to understand students' views on the use of video-recorded speaking task. Table 6 illustrates the data which are categorized into positive and negative responses.

Responding the first question, most students (36 students out of 43) viewed that the task was positive by stating that it was new, beneficial, and fascinating making students not easily bored. It also provided them opportunities to have more exercises to train their oral productive skill, learn new vocabularies and how to pronounce these vocabularies, develop their ideas, and let students experience new ways of learning English. In addition, they also considered that producing the video enabled them develop their confidence in speaking and develop their discipline, moreover in collecting the video. Nonetheless, there were also other learners who considered that this task was not easy to carry out, took quite long time to finalize as it involved both preparation and revision, and sometimes confusing. Those stating good responses also admitted that they faced some problems when finishing their tasks, which merely due to their personal problems such as being lazy, which caused them submit their work late.

Table 6. The Result of Questionnaire

\begin{tabular}{|c|c|c|c|}
\hline No & Questionnaire & $\begin{array}{l}\text { Positive } \\
\text { response } \\
\mathrm{s}\end{array}$ & $\begin{array}{l}\text { Negative } \\
\text { response } \\
\mathrm{s}\end{array}$ \\
\hline 1 & $\begin{array}{l}\text { What is your } \\
\text { opinion of the } \\
\text { using } \\
\text { video-recorded } \\
\text { speaking task? }\end{array}$ & $\begin{array}{l}36 \\
\text { students }\end{array}$ & $\begin{array}{l}7 \\
\text { students }\end{array}$ \\
\hline 2 & $\begin{array}{l}\text { What did you like } \\
\text { in the using } \\
\text { video-recorded } \\
\text { speaking task? }\end{array}$ & $\begin{array}{l}40 \\
\text { students }\end{array}$ & $\begin{array}{l}3 \\
\text { students }\end{array}$ \\
\hline 3 & $\begin{array}{l}\text { What } \\
\text { advantage(s) did } \\
\text { you get from the } \\
\text { using of video } \\
\text { recorded-speakin } \\
\text { g task? }\end{array}$ & $\begin{array}{l}43 \\
\text { students }\end{array}$ & 0 student \\
\hline 4 & $\begin{array}{l}\text { How is your } \\
\text { impression after } \\
\text { doing } \\
\text { video-recorded } \\
\text { speaking task? }\end{array}$ & $\begin{array}{l}40 \\
\text { students }\end{array}$ & $\begin{array}{l}3 \\
\text { students }\end{array}$ \\
\hline
\end{tabular}


Additionally, the students also mentioned what they like in following this new type of lesson. Some of them contended that they had the opportunity to develop their oral productive skill without hesitation and that they could have sufficient time to analyze and revise their performance when made mistakes. What was more important according to them was that they could learn expressing their ideas orally and confidently.

However, they did not like making the video because they had a lot of work and the video creation took a long time especially they also had to revise when they made mistakes. Consequently, they had to edit and reproduce the video, which they said they did not really like doing. In addition, according to the students, the duration of the video was too long, which made them less motivated to complete the task on time. Other problems they complained were related to expenses of internet quota and camera quality affecting the production of the video.

\section{Discussion}

This study shows that video-recorded speaking task played an effective role in improving students' oral productive skill as evidences from the significantly higher scores of the experimental group in both the post-test and gain scores. Thus, the findings have confirmed the hypothesis assumed in the study that video-recorded speaking tasks would enhance students' oral productive skill. At the same time, the results also strengthen some relevant previous studies such as those carried out by Gromik (2013) and Castaneda and Gonzales (2011) on the effectiveness of video-recorded speaking tasks in improving students' oral productive skill.

Resembling the abovementioned previous studies, this study also used video recording as a way to enhance students' oral productive skill. Yet, of course there were some differences especially in terms of the design and the sample. That of Castaneda and Gonzales (2011) for instance involved only 9 students in an intermediate conversational class because the study was a qualitative one and hence there was no control class. In other words, all of them joined the intervention. However, the design of this study was quasi-experimental, which involved both the experimental and control groups. There was an intervention in the experimental group while the control one attended regular teaching and learning process.

Furthermore, concerning the analysis, only descriptive statistics analysis was used in analyzing the data in the above previous studies while this study combined both descriptive and statistical analyses of students' scores in pretest and post-test for testing the hypothesis. The descriptive findings showed that there was an improvement in both the experimental and control groups. As expected, nonetheless, the 
statistical analysis (t-test) highlighted that only the improvement in the experimental class was significant indicating the effective role on video-recorded speaking tasks in enhancing students' oral productive skill.

Furthermore, in this study, student questionnaire was also used to know what students view about the use of video-recorded speaking tasks. Another similar study conducted by Karasic and Vedantham (2015) also collected the data of not only students' but also faculty members' views as well as reflections through observations and interviews to understand their perspective on the roles of video in language learning experience. Nevertheless, in this paper, the data coming from students' questionnaire were perceived as secondary intended to provide additional information to the results of the statistical analysis students' scores. As previously mentioned, most students considered that the task was different from their previous tasks and therefore they were motivated to do the task. They also admitted that the tasks provided more learning opportunities to develop their oral productive skills. This finding is in line to the findings of Karasic and Vedantham (2015) which revealed that the use of video was useful in training speaking skill.

Furthermore, the students stated that this kind of practice helped them build their confidence as they could practice expressing their ideas orally without any hesitation. As has been argued by Dal (2015), video-recorded speaking task can provide sufficient opportunity for students to express their ideas with good arrangement of material and vocabulary due to available time for preparation. In addition, students can easily improve their confidence because they are able to revise their videos when they find mistake (Castaneda \& Gonzales, 2011).

Moreover, the findings coming from students' questionnaire could provide further explanation why students in the experimental group were able to enhance their oral productive skill. Students were facilitated to have more opportunities to build their speaking ability in their own time. This is in line with the idea offered by Gebhard (2006) that the limited practice available in the classroom could be responded by the use of video-recorded speaking task. In addition to providing sufficient time to practice, it has been argued as well that this type of task can build students' confidence as they can previously prepare and revise when there are mistakes, which means that language anxiety could be addressed appropriately (Harmer, 2007).

However, it is also important to note that video-recorded speaking task is not exempt from weaknesses. As has been acknowledged by Gromik (2013), most students viewed this task to be quite complicated. The participants of 
this study also reported various complains such as limited internet connection, compatibility of their mobiles, and other demanding school assignments with short available time.

\section{CONCLUSION}

This study was intended to measure the role of video-recorded speaking task in enhancing students' oral productive skill. The statistical analysis of the post-test and gain scores clearly revealed that students in the experimental group achieved significantly higher speaking score indicating the effective role of video-recorded speaking task. Beside distributing test, this study also disseminated students' questionnaire to ask students' views about the task, which findings further explained that the task was effective to improve students' oral productive skill. The students considered that this kind of practice gave them more opportunities to speak confidently, assisted them deliver better speaking materials and ideas, and provided unique and joyful experience in developing speaking ability. Yet, few of them also recognized the complexity of the task amidst other heavy school assignments. Finally, further research may conduct a deeper investigation by employing a mixed method in order to have a thorough understanding the use of video-recorded speaking task and its effects on speaking skill in Indonesian context.

\section{REFERENCES}

Azkiyah, S.N., Doolaard, S., Creemers, B.P.M., \& Van Der Werf, M.P.C. (2014). The effects of two intervention programs on teaching quality and student achievement. Journal of Classroom Interaction, 49(1), 4-11.

Canale, M. \& Swain, M.(1980). Theoritical bases of communicative approach to second language teaching and testing. Applied Linguistic, 1(1), 1 43. doi:10.1093/applin/I.1.1. Retrieved from http://applij.oxfordjournals.org/.

Castañeda, M., \& Rodríguez-González, E. (2011). L2 speaking self-ability perceptions through multiple video speech drafts. Hispania, 94(3), 483-501. doi: 10.1353/hpn.2011.0066. Retrieved from

http://www.jstor.org/stable/230 32122.

Chambers, L. \& Dean, C. (2000). Noteworthy perspectives on implementing standards-based education. Washington D.C.: Mid-Continent Research for Education, and Learning.

Chen \& Hsu. (2008). Personalized intelligent mobile learning system for supporting effective english 
learning. Educational Technology $\mathcal{E}$ Society, 11(3), 153-180 .doi: 10.1109/ICSMC.2006.385081.

Retrieved from http://www.jstor.org/stable/jed uctechsoci.11.3.153.

Cheng, Han-Yin. (2008). The effects of the role play instructional model on Taiwanese ESL students' learning attitude, social skill and oral performance. La Sierra University.

Cohen, L., Manion, L. and Morrison, K. (2000). Research Methods in Education, 5th ed. London and New York: Routledge Falmer.

Crystal, D. (2003). English as a global language, 2nd ed. Cambridge: Cambridge University Press.

Dal, M. (2012). Digital video production and foreign language learning. In T. Amiel \& B. Wilson (Eds.), Proceedings of EdMedia: World Conference on Educational Media and Technology 2012. Association for the Advancement of Computing in Education (AACE). Retrieved from www.learntechlib.org

Donough, Mc., \& Shaw, C. (1993). Materials and methods in ELT; A teacher's guide. Oxford: Blackwell.

Dowson, M., McInerney, D. M., \& Van Etten. (2007). The state of play in standards and standards reform. In McInerney, D. M., Van Etten, S., \& Dowson, M. Standards in education.
Charlotte, NC: Information Age Publishing.

Fulcher, G. (2003). Testing second language speaking. NewYork: Pearson Longman

Gebhard, Jerry G. (2006). Teaching English as a foreign language or second language. Michigan: University of Michigan Press.

Gromik, Nicholas. (2013). Investigation of the cellphone video recording feature by Japanese undergraduate EFL learners. Unpublished Ph.D Thesis. James Cook University. Retrieved from

http://researchonline.jcu.edu.au/ 40269/.

Gunn, Amanda M. (2007, August 10). Relational communication as a central focus for the "Communication Across the Curriculum" initiative. Across the Disciplines, 4. Retrieved from https://wac.colostate.edu/atd/ar ticles/gunn2007.cfm.

Hamideh, A., Rostampour, M., Abdorahimzadeh, S.J. (2015).The role of brainstorming In enhancing Iranian EFL learners' speaking progress and achievement. Modern Journal of Language Teaching Methods 5(2),157-158.

Harmer, J. (1991). The Practice of English language teaching. London: Longman. 
Harris, David P. (1969). Testing English as a foreign language. New York: McGraw-Hill Publishing Company Ltd.

Jeng, Y.-L., Wu, T.-T., Huang, Y.-M., Tan, Q. \& Yang, S. J. H. (2010). The add-on impact of mobile applications in learning strategies: a review study. Educational Technology \& Society, 13, 3-11. Retrieved from http://www.jstor.org/stable/jed uctechsoci.13.3.3.

Karasic, V.M. \& Vedantham, A. (2015). Video creation tools for language learning: lessons learned. Scholarship at Penn Libraries, Paper 87, 107-128. Retrieved from http:// repository.upenn.edu/libr ary_papers/87.

Liu, M. (2009). Reticence and anxiety in oral English lessons. Bern: Peter Lang.

Liu, Xu.(2013) Arousing the college students' motivation in speaking english through role-play. International Education Studies, 3(1).136-144. doi: 10.5539/ies.v3n1p136 Retrieved from

files.eric.ed.gov/fulltext/EJ106606 6.pdf.

Marwan, A.(2008). The exploration of factors triggering foreign language anxiety: learners' voice. TEFLIN (Teaching English as a
Foreign Language in Indonesia) Journal, 19(2), 119-126.

Miangah,T. M. \& Nezarat, A.(2012). Mobile-assisted language learning. International Journal of Distribution and Parallel System, 3(1), 310-319. doi: 10.5121/ijdps.2012.3126.

Morreale, S. P., \& Pearson, J. C. (2008). Why communication education is important: The centrality of the discipline in the 21st century. Communication Education, 57(2), 224-240. doi:10.1080/03634520701861713.

Oxford, R. (2002). Sources of variation in language learning. In R. B. Kaplan (Ed.), The Oxford handbook of applied linguistics, 245-252. Oxford: Oxford University Press.

ÖztÜrk, G., \& GÜrbÜz, N. (2014). Speaking anxiety among Turkish EFL learners: The case at a state university. Journal of Language and Linguistic Studies, 10(1), 1-17.

Pishkar, K., Moinzadeh, A., \& Dabaghi, A. (2017). Modern english drama and the students' fluency and accuracy of speaking. English Language Teaching 10(8), 69 -77.

Richard, J.C. \& Rodgers, T.S. (2001). Approaches and methods in language teaching: A description and analysi. New York: Cambridge University Press. 
Shahsavar, Z. \& Tan, B. H. (2011). Does cognitive style affect bloggers' attitude in an online learning environment? GEMA Online ${ }^{\mathrm{TM}}$ Journal of Language Studies, 11(1), 159-171.

Sturiale, K.A. (2013). Teaching public speaking skills through theater activities. Unpublished Dissertation. California: Saint Mary's College of California.

Tai. Y. (2012). Contextualizing a MALL: practice design and evaluation. Educational Teachnology \& Society, 15(2), 220-230. Retrieved from http://www.jstor.org/stable/jed uctechsoci.15.2.220.
Urrutia León, W., \& Vega Cely, E. (2010). Encouraging teenagers to improve speaking skills through games in a Colombian public school. PROFILE Issues in Teachers' Professional Development, 12(1), 11-31.

Yarahmadi, S., Bonyadi, A. \& Rimaninikou, F. (2015). The effect of discussion-based activities on the speaking ability of iranian intermediate EFL female English learners. Modern Journal of Language Teaching Methods, 5(2), 412-413. 